\title{
O DRAMA HISTÓRICO DO NEGRO NO TEATRO BRASILEIRO E A LUTA ANTIRRACISMO NAS ARTES CÊNICAS (1840-1950) ${ }^{16}$
}

Gabriel dos Santos Rocha ${ }^{17}$

\section{Resumo}

Este artigo abordará a presença do negro nas artes cênicas brasileiras do Segundo Império (1840-1889) - quando o teatro se tornava um ambiente restrito às classes dominantes, os negros eram representados em imagens fortemente ligadas a escravidão e as peças eram carregadas de conteúdo racista - ao Pós-Estado Novo, quando Abdias Nascimento fundou o Teatro Experimental do Negro (1944-1968), visando reverter tal quadro. Analisaremos o processo histórico de mudanças nas representações dos afro-brasileiros nas artes cênicas, enfatizando os esforços empreendidos pelos próprios negros no combate aos estereótipos e imagens pejorativas recorrentes nas produções dramatúrgicas. Podemos caracterizar tais esforços como parte de uma estratégia de luta do antirracismo pela via cultural, na qual o Teatro Experimental do Negro foi um importante expoente.

\section{Palavras-chave}

História do teatro; teatro negro; movimento negro; racismo; antirracismo

\section{Abstract}

This article will address the presence of the black in the Brazilian performing arts of the Second Empire (1840-1889) - when the theatre became an environment restricted to the ruling classes, blacks were represented in images strongly linked to slavery and the plays were loaded with racist content - to the Post-Estado Novo, when Abdias Nascimento founded the Teatro Experimental do Negro (1944-1968), in order to reverse this situation. It will analyze the historical process of changes in the representations of Afro-Brazilians in the performing arts, emphasizing the efforts made by blacks themselves in opposing stereotypes and recurrent pejorative images in dramaturgical productions. We can characterize these efforts as part of a strategy of anti-racism by the cultural route, in which the Teatro Experimental do Negro was an important exponente.

\section{Keywords}

History of theatre; black theatre; black movement; racism; anti-racism

\footnotetext{
$16 \mathrm{O}$ presente artigo é resultado de modificações feitas no item "2.3 O TEN e o negro no teatro brasileiro" contido na dissertação de mestrado do autor O negro como tema e sujeito na produção intelectual de Abdias do Nascimento, 1944-1968, realizada com bolsa FAPESP, defendida no Departamento de História Social da FFLCH/USP, em maio de 2016

17 Graduado em história e mestre em história social, ambos pela Universidade de São Paulo. É escritor/documentarista na Companhia Teatro da Investigação, e professor de história.
} 
Em outras palavras, o negro não deve mais ser colocado diante deste dilema: branquear ou desaparecer, ele deve poder tomar consciência de uma nova possibilidade de existir; ou ainda, se a sociedade lhe cria dificuldades por causa de sua cor, se encontro em seus sonhos a expressão de um desejo inconsciente de mudar de cor, meu objetivo não será dissuadílo, aconselhando-o a "manter as distâncias"; ao contrário, meu objetivo será, uma vez esclarecidas as causas, torná-lo capaz de escolher a ação (ou a passividade) a respeito da verdadeira origem do conflito, isto é, as estruturas sociais.

Frantz Fanon, Pele negra, máscaras brancas ${ }^{18}$

\section{Uma breve nota sobre o racismo no teatro e na sociedade}

O trecho acima que nos serve de epígrafe traz a perspectiva de Frantz Fanon sobre o racismo. Para o pensador martinicano, a opressão racial não poderia ser compreendida dissociadamente das estruturas sociais que a engendravam. Naquele contexto, Fanon tinha como objeto de análise, sobretudo, as sociedades coloniais francófonas. Embora originadas em determinado recorte temporal e espacial, as reflexões deste psiquiatra e revolucionário negro, são pertinentes para a compreensão das relações assimétricas entre diferentes grupos em sociedades multirraciais diversas. Para Fanon "uma sociedade é racista ou não é"19. Cabe a nós considerarmos as particularidades de cada processo histórico-social, porém seria incoerente compararmos as variáveis da opressão racial entre diferentes sociedades com a finalidade de mensuramos qual sociedade é mais, ou menos, racista. O que nos interessa, é analisarmos o fenômeno da opressão racial partindo de nossa realidade social com a finalidade de superá-la ${ }^{20}$. Combater o racismo na sociedade: acreditamos que essa seja a finalidade dos estudos que se debruçam sobre este tema.

Compreender o racismo em relação às estruturas sociais é entendê-lo enquanto fato histórico, tão histórico quanto a própria formação da sociedade, as relações de produção, o sistema político e a cultura. O racismo produz a sociedade, ao mesmo tempo em que é por ela produzido. No sistema capitalista, a opressão racial se relaciona com a opressão de classe; se expressa na distribuição desigual dos meios de aquisição de bens materiais, e na negação de determinados direitos. Nas relações de produção em que os trabalhadores são espoliados ao venderem a mão-deobra, as pessoas pertencentes aos grupos racialmente oprimidos são intensamente mais espoliadas

18 Fanon. P.95-96

19 Fanon. Idem. P.85

20 Sobre a função social do conhecimento sobre a realidade, vale lembrarmos da décima primeira tese de Marx sobre Feuerbach: "Os filósofos apenas interpretam o mundo de diferentes maneiras; porém, o que importa é transformálo. A ideologia alemã. P.539 
do que as pertencentes ao grupo racial dominante, e geralmente ocupam os postos de menor prestígio, ou de maior degradação. Em sociedades multirraciais, como o Brasil que é marcado pela presença de brancos, negros e indígenas, a opressão racial historicamente recai sobre os dois últimos grupos, que estão representados nos setores mais desfavorecidos. O racismo funciona como um mecanismo de estratificação social que mantém os brancos em condições socialmente privilegiadas em detrimento dos demais grupos étnicos ${ }^{21}$.

A economia, a política e a cultura são fatos históricos chaves para entendermos as estruturas sociais que produzem e que são produzidas pelo racismo. O teatro é uma forma de manifestação cultural, portanto, também está integrado a essas estruturas (junto com os fatos políticos e econômicos). É fruto de uma sociedade em seu tempo histórico. Estando no âmbito da cultura, o teatro opera no sistema de referências do social: produz e reproduz valores, signos, símbolos, modos de vida, saberes; e pode ser tanto um espaço de manutenção da cultura hegemônica, quanto um espaço de contestação, instrumento de contra-hegemonia. Neste ponto residirá nossa análise: abordaremos as relações raciais no teatro brasileiro, mais especificamente, as representações do negro em diferentes períodos das artes cênicas no Brasil, entendendo o teatro como fator cultural correspondente ao contexto histórico e social no qual se manifesta. Podemos afirmar que o racismo no teatro é o racismo da sociedade. Portanto, o combate ao racismo nas artes cênicas integra-se ao movimento antirracismo na sociedade.

\section{Da máscara branca aos estereótipos da Comédia de Costumes e do Teatro de Revista}

A presença ou a ausência, do negro no teatro brasileiro correspondem aos diferentes contextos de nossa história, e se relacionam com o espaço e os valores atribuídos às artes cênicas nos diferentes períodos. Miriam Garcia Mendes em seu livro O negro no teatro brasileiro aponta para a presença de um tipo de teatro negro no Brasil na segunda metade do século XVI "quando, no periodo natalino os escravos promoviam representações de seus autos profanos: a Congada, ou Congo, as Taieiras, o Quicumbre, os Quilombos", danças dramáticas de origem africana

21 Há uma vasta bibliografia que analisa as relações raciais no Brasil e apontam para a disparidade entre negros e brancos. Citamos apenas alguns estudos que se tornaram referência: Fernandes, A integração do negro na sociedade de Classes; Guimarães, Classes, Raças e Democracia; Hasenbalg e Silva, Estrutura social, mobilidade e raça; Moura, Dialética radical do Brasil negro; Munanga, Rediscutindo a mestiçagem; Nascimento, O genocídio do negro brasileiro. 
reelaboradas no período colonial sob influência dos autos portugueses e franceses da Idade Média ${ }^{22}$. Estas danças dramáticas populares de origem africana distinguem-se do teatro de formato europeu, porém, a influência ibérica nelas pode ser identificada nos autos que reverenciam figuras do catolicismo como Nossa Senhora do Rosário, São Benedito, Santa Ifigênia, São Sebastião, o Divino Espírito Santo, e outros ${ }^{23}$.

Mendes nos informa que entre a segunda metade do século XVIII e os primeiros anos do século XIX existiam companhias teatrais profissionalizadas com elencos predominantemente formados por negros e mestiços, escravos ou libertos que interpretavam personagens brancas com as mãos e os rostos pintados de branco.

\begin{abstract}
"Alguns desses negros chegariam a ser famosos atores, como Vitoriano, exescravo, que em 1790 maravilhou o público presente aos festejos promovidos por um Toledo Rendon, de Cuiabá, com seu desempenho na peça Tamerlão na Pérsia. Dois outros escravos, o par Caetano Lopes dos Santos e Maria Joaquina, também se notabilizaram nos papéis de Rei e Rainha de Congada, espetáculo apresentado no Rio de Janeiro, em 1811, com enorme sucesso"24.
\end{abstract}

Esta presença de negros e mestiços no teatro é explicada pelo fato de a profissão de ator neste período ser considerada desprezível e infame. Porém, em meados do século XIX, quando o teatro tornou-se um espaço de requinte para as classes dominantes, os negros e mestiços foram tirados de cena. A partir de então as personagens negras, quando apareceram, passaram a ser interpretadas por atores brancos pintados de preto.

Entre meados do século XIX até as primeiras décadas do XX disseminou-se no Brasil a comédia de costumes. Trata-se de um gênero que se utiliza da sátira para retratar temas de uma determinada sociedade em uma época específica (os dramaturgos desse gênero geralmente abordam a sociedade de seu próprio tempo). Suas origens são atribuídas aos dramaturgos franceses Molière (1622-1673) e Pierre Corneille (1606-1684). O primeiro autor que escreveu peças desse gênero no Brasil foi Martins Pena, considerado por seus contemporâneos como "o Molière brasileiro"25.

De 1850 até a abolição em 1888, a imagem veiculada sobre o negro no teatro brasileiro se

22 Miriam Garcia Mendes, $O$ negro no teatro brasileiro. P.48

23 Auto é uma "denominação genérica dada às representações teatrais na Península Ibérica desde o século XIII. Aplicava-se indistintamente às composições dramáticas de caráter religioso, moral ou burlesco". Guinsburg, Faria e Lima (coord.), Dicionário do Teatro Brasileiro: temas formas e conceitos. P.48

24 Miriam Garcia Mendes. Idem. P.48

25 Guinsburg, Faria e Lima (coord.), Idem. P.97 
resumia à figura do escravo, reforçando a ideia de que "negro" e "escravo" eram equivalentes ou sinônimos - ser negro era ser escravo -, mesmo quando a proporção de negros alforriados tornavase cada vez mais significativa, como ocorria naquele período ${ }^{26}$. Esta imagem do negro escravo, levada aos palcos do teatro, era carregada do "evolucionismo" racista de Agassiz, Lombroso, Gobineau e tantos outros ideólogos - na época reconhecidos como 'homens de ciência'- que classificavam o negro como menos dotado de humanidade do que o branco, quando não, completamente destituído de humanidade. $\mathrm{O}$ resultado era a criação de personagens secundárias e sem valor dramático como nas peças do referido fundador da comédia de costumes no Brasil, Martins Pena, Juiz de Paz na roça (1843), Um sertanejo na corte (1833-37), O namorador, A noite de São João (1844), O cigano (1845), onde as personagens negras sequer têm nome, são identificadas como "um mulato escravo", "dois negros", "negros e moleques" "mucamas"; ou quando tinham algum valor dramático eram personagens caracterizadas por "vícios naturais" da raça.

Estas também são características das personagens negras das peças do romântico José de Alencar, $O$ demônio familiar e $A$ mãe ambas de 1857, onde os negros são maliciosos, malandros, mentirosos, invejosos e até mesmo "ingratos" com seus senhores, como a personagem Pedro de $O$ demônio familiar; ou extremamente submissos, passivos e ingênuos, como Joana de $A$ mãe. Outro estereótipo que marcou a representação do negro nas artes cênicas brasileiras é a "mulata sensual" como a personagem Carlota de Gonzaga ou a Revolução de Minas (1867) de Castro Alves, e Benvinda da peça A Capital Federal (1897) do dramaturgo de revista Arthur Azevedo que encarna a tipificação da "mulata libidinosa" 27 . Cada peça e autor mencionado neste parágrafo têm suas peculiaridades estéticas, temáticas e políticas, mas servem para exemplificar a persistência de alguns estereótipos sociais, historicamente construídos sobre os negros, nas artes cênicas.

Na primeira metade do século XX disseminou-se no Brasil o gênero "teatro de revista". Semelhante à comédia de costumes - ainda em voga durante a Primeira República - o teatro de revista polemiza e satiriza os hábitos comuns na sociedade e a vida política de sua época. Os textos geralmente são cômicos, irônicos, com trocadilhos de duplo sentido e metáforas maliciosas. São temas correntes: casamentos arranjados, subornos, conflitos entre valores morais na cidade e no campo, artimanhas políticas, o mau funcionamento das instituições políticas, civis e religiosas,

26 Mendes, Ibidem.

27 Christian Moura, O Teatro Experimental do Negro - Estudo da personagem negra em duas peças encenadas. P.2531 
desarranjos entre classes sociais, os estrangeirismos, entre outros. Era comum nesta vertente cênica, a comicidade dos acontecimentos culturais sociais e políticos, e a utilização de "personagens tipos" (que representam uma coletividade ou um grupo) como o malandro, a mulata, o português, o imigrante (italiano na maioria dos casos), o caipira. Os enredos tinham como pano de fundo a vida operária, os cortiços, favelas e subúrbios, os costumes públicos e privados das famílias rurais e urbanas, o cenário político; na década de 1920 eram ironizados a queda de antigas oligarquias e a crise política da República Velha. Os números musicais eram comuns neste tipo de teatro: havia quadros com ritmos nacionais, principalmente o samba, o maxixe e marchas carnavalescas ${ }^{28}$. Luiz Peixoto e Carlos Bittencourt foram os dois autores que mais se destacaram no teatro de revista. No entanto o gênero também contou com dramaturgos como Armando Gonzaga, Leopoldo Fróes, Oduvaldo Vianna, Procópio Ferreira e Viriato Correa. Dentre os compositores que tiveram importância para o teatro de revista estão Ari Barroso, Sinhô, Assis Valente e Noel Rosa ${ }^{29}$.

Do gênero de revista, a peça Forrobodó (1912) de Luís Peixoto e Carlos Bittencourt, com música da compositora e maestrina Chiquinha Gonzaga, se utilizou de uma série de estereótipos atribuídos aos negros: mulata dengosa e casadoira, mulata sensual, mulato capoeirista briguento, malandro festeiro e avesso ao trabalho. Na comédia de costumes Terra Natal (1920) de Oduvaldo Vianna as personagens negras são os empregados da fazenda: Benedicto, um menino peralta, engraçado e ignorante; Felisbina, menina dócil, ingênua, e ignorante; e Carmen, "mulata faceira", prostituta carioca $^{30}$.

O teatro de revista buscava representar os "tipos populares" e ao longo da primeira metade do século XX tornava-se cada vez mais um gênero de expressão popular e nacional, pois trazia, tanto nos enredos, quanto nos cenários e nas trilhas sonoras de suas peças, elementos que remetiam aos ideais de cultura nacional buscados pelos artistas e intelectuais da época, como por exemplo a mestiçagem - o português apaixonado pela mulata sedutora era um tema recorrente - e os ritmos nacionais, como o samba e as marchinhas carnavalescas, tidos como expressões do povo. Neste contexto artistas negros e mestiços começaram a aparecer, e divulgar seu trabalho nos palcos através do gênero da revista.

A presença do negro nas artes cênicas brasileiras do século do XIX até as duas primeiras décadas do XX - quando o teatro se tornara ambiente de encontro das classes dominantes - se

28 Moura, Idem. P. 31-37

29 Guinzburg, Faria, Lima (coord.), Dicionário do Teatro Brasileiro. Temas formas e conceitos. P.296-297

30 Moura, 2008. P.37-41 
restringia à participação como músico, junto à orquestra que geralmente não aparecia no palco (ficava escondida em um fosso entre o palco e a plateia). $\mathrm{O}$ artista negro era impedido de mostrarse. Na década de 1920, os músicos começaram a aparecer nos palcos onde eram apresentadas peças do teatro de revista, e passou a ser destacada a presença das coristas, muitas delas negras ou mestiças $^{31}$. Nesta mesma década surgiu uma iniciativa - talvez a primeira no Brasil - de protagonismo de atores negro nos palcos, que, no entanto, teve de enfrentar as adversidades de uma sociedade racista, pretensamente branca, que investia contra qualquer forma - ou tentativa - de protagonismo negro nas artes cênicas e no cenário social como um todo.

\section{Companhia Negra de Revistas: esboçando o protagonismo negro sob a pena branca}

Em julho de 1926 no Rio de Janeiro, no Teatro Rialto, estreou o primeiro grupo de teatro formado por atores e atrizes negras, a Companhia Negra de Revistas (CNR), fundada pelo artista baiano João Candido Ferreira, também conhecido como De Chocolat, e pelo cenógrafo português Jaime Silva, reunindo atores, atrizes e músicos, alguns dos quais já consagrados na época: Bonfiglio de Oliveira, Alfredo da Rocha Vianna Filho (mais conhecido como Pixinguinha), Guilherme Flores, Jandira Aimoré e Rosa Negra; ainda desconhecidos do público na época: Dalva Espíndola, Mingote e Osvaldo Viana. A companhia durou um ano, dissolvendo-se em julho de 1927, porém seis meses antes de findar, integrou-se ao grupo um ator que se tornaria a principal atração, Sebastião Bernardes de Souza Prata, na época com 11 anos de idade, apelidado de Pequeno Otelo, que anos depois se tornaria o renomado ator - também compositor e cantor - Grande Otelo ${ }^{32}$.

Monsieur De Chocolat, foi o apelido que João Candido Ferreira ganhou quando esteve excursionando em um festival de variedades artísticas em Paris, na década de 1920. Naquela ocasião havia um crescente interesse pela cultura - principalmente pela arte - de matriz africana entre os artistas europeus que buscavam renovar-se esteticamente, destacando-se as vanguardas cubista, surrealista e dadaísta. Neste período, artistas afro-americanos, sobretudo músicos e dançarinos, ganharam destaque nos palcos da capital francesa, onde crescia o interesse pelo jazz e ritmos afro-caribenhos. Em 1925 no teatro do Champs-Élysées estreou o espetáculo Revue Nègre que tinha como atração principal a dançarina negra estadunidense Josephine Baker, acompanhada

31 Jeferson Bacelar, "A história da Companhia Negra de Revistas". P.438

32 Bacelar, "A história da Companhia Negra de Revistas"; Nepomuceno, Testemunhos de poéticas negras: de Chocolat e a Companhia Negra de Revistas do Rio de Janeiro (1926-1927); Moura, O Teatro Experimental do Negro - Estudo da personagem negra em duas peças encenadas. 
por um grupo de dançarinas afro-americanas. Este espetáculo inspirou De Chocolat a fundar, quando retornou ao Brasil, a Companhia Negra de Revistas (CNR), considerada a primeira companhia teatral afro-brasileira ${ }^{33}$.

Dentre as dificuldades enfrentadas pela CNR, além da escassez financeira, houve a recepção negativa permeada de racismo por uma parte do público, da crítica e da comunidade artística. Jornais da época como A Rua, os acusavam de estarem imitando o espetáculo parisiense Revue Nègre. A modernista Tarsila do Amaral considerava pedante o nome "De Chocolat", assim como considerou pedante a atuação deste artista no palco. Talvez a modernista estivesse acostumada e ver o negro representado, mas não representando, sendo objeto, mas não sujeito daquela arte.

Quando alguns setores da classe teatral, dentre eles a Sociedade Brasileira de Autores Teatrais, souberam que uma empresa Argentina convidava a Companhia para uma excursão na Argentina e no Uruguai, organizaram-se então para impedir que fosse levado tal "imagem negativa" do Brasil para os países vizinhos. O antropólogo Jeferson Bacelar comenta o episódio:

"Uma revista do Rio de Janeiro especializada em teatro, entre outras considerações, arguia: "Não é o caso dos poderes públicos, principalmente do Ministério das Relações Exteriores, evitar essa propaganda do nosso país e, logo onde, na República vizinha e amiga?". A notícia repercutiu na SBAT (Sociedade Brasileira de Autores Teatrais), que, com grande relação com os circuitos do poder, reuniu seu Conselho Deliberativo e deliberou contra a excursão, pois, como a mesma "redundará em descrédito do nosso país, a SBAT, como lhe cumpre, irá agir energicamente a fim de impedir a consumação desse atentado aos foros de nossa civilização". Foram além, declarando que iriam constituir uma comissão para convencer a Companhia a desistir de seu intento e, caso insistisse, teria a SBAT "de agir por meios mais eficazes". A Companhia não apenas desistiu da excursão, ali foi passado também seu atestado de óbito"34.

A Companhia Negra de Revistas, estilizou os números do gênero de revista com danças e canções inspiradas na cultura afro-brasileira e afro-americana, e suas peças constantemente faziam menção à cor negra, como um marcador identitário, uma demonstração de que os negros não deveriam ter receio em assumirem-se negros, ainda que essa identidade fosse baseada em 
estereótipos, um tanto pejorativos, correntes na época, como demonstram os títulos das peças Carvão nacional, e Café torrado. Outros espetáculos apresentados pela companhia foram, Preto e branco, e Tudo Preto (com o qual estreou). A originalidade da CNR está no fato de ser um grupo teatral onde os negros eram protagonistas da elaboração e execução das atividades cênicas. A presença dos atores, atrizes e músicos negros (executando música de matriz negra) exemplifica a organização de um grupo afro-brasileiro com o objetivo de afirmar-se através das artes diante de uma sociedade onde os negros eram marginalizados e excluídos de espaços que eram reservados aos brancos, dentre eles o teatro. Evidentemente trata-se de uma iniciativa pioneira ao incluir o negro como protagonista nas artes cênicas, porém, cabe lembrarmos que a CNR, embora representeasse também uma renovação estética nos palcos, não ultrapassou os limites das imagens estereotipadas referente aos negros, veiculadas nos demais espetáculos do teatro brasileiro de sua época.

No entanto, mesmo com esses limites vemos que o grupo de João Candido Ferreira causou incômodo nos meios dominantes, gerando uma mobilização no próprio meio artístico que recebeu com estranhamento e hostilidade a proposta de um teatro negro.

\section{O Teatro Experimental do Negro: a questão racial debatida para além dos palcos}

O Brasil veio a conhecer outra companhia de teatro negro de considerável envergadura somente duas décadas depois. Em 13 de outubro de 1944, no Rio de Janeiro, Abdias Nascimento, Sebastião Rodrigues Alves e Aguinaldo de Oliveira Camargo fundaram o Teatro Experimental do Negro (TEN), que veio a se tornar uma referência na luta histórica do movimento negro contra o racismo. Durante sua existência no Brasil - que se encerrou com o exílio de Abdias nos EUA a partir de 1968 - o TEN lutou pela inserção do negro como protagonista nas artes cênicas, porém, não há outra semelhança além desta entre o grupo cênico afro-brasileiro do pós-Estado Novo e a companhia de João Candido Ferreira (De Chocolat) da década de 1920.

É recorrente nos depoimentos e textos de Nascimento a diferenciação pautada entre o TEN e o que tradicionalmente vinha sendo produzido referente aos negros no teatro brasileiro desde o século XIX até a primeira metade do XX. As diferenças entre as companhias teatrais de Ferreira e de Nascimento associam-se à distinção entre o contexto histórico da década de 1920 e o da década de 1940. A CNR não teve mais que um ano de existência (1926-1927) na "Primeira República", no período em que o movimento negro brasileiro era representado principalmente pela imprensa negra 
e pelos clubes sociais e associações de caráter recreativo. Podemos dizer que a fundação da CNR fez parte de um mesmo movimento reivindicativo de espaço para os afro-brasileiros na sociedade civil e na cultura nacional, que se manifestou através de seus próprios periódicos e associações comunitárias. Mas não há um vínculo organizativo direto entre a companhia de Chocolat e as entidades sociais negras daquela época. Salvo o contexto de reivindicações pela inserção social dos afro-brasileiros, a CNR existiu independentemente dos jornais, clubes e associações negras.

O TEN foi fundado no fim da segunda guerra mundial e da ditadura do Estado Novo, duas décadas depois da CNR. O movimento negro já tinha em sua história a Frente Negra Brasileira, que foi uma organização política e de massas, pela qual Abdias Nascimento havia passado - onde iniciou sua militância -, adquirindo experiência política e de organização. Na escolha das peças e na atuação em palco, o grupo de Abdias buscou superar estereótipos em torno das personagens negras, recorrentes nas comédias de costumes e no teatro de revista (ao qual a CNR vinculava-se). As peças do TEN se desvinculavam daquelas que se restringiam a apresentar o afro-brasileiro em tipos como o escravo, o moleque da fazenda, o malandro avesso ao trabalho, o capoeirista encrenqueiro, a mulata sensual e assanhada, a "mãe-preta"/ama-de-leite, rompendo, deste modo, com as representações estereotipadas do negro difundidas nos meios artísticos e intelectuais de sua época. As personagens também deixaram de ter como características principais a preguiça, a postura desastrada e atrapalhada, a burrice ou a libido exagerada. O TEN não apenas incluiu os negros como protagonistas nos palcos, como também ampliou as possibilidades dos atores trabalharem sua dramaticidade, para além dos limitados papéis que até então eram reservados a eles ${ }^{35}$.

A ruptura com estereótipos em alguns casos levou Abdias Nascimento a se utilizar da substituição de uma imagem essencializada do negro por outra, por exemplo: na peça Sortilégio, de sua autoria, - já mencionada - a imagem do negro cristão de classe média que assimilou os valores eurocêntricos tem como contraponto o negro adepto do candomblé que rejeita todos os valores identificados na 'cultura do opressor'. É o caso da personagem Dr. Emanuel, que se liberta (simbolicamente) da opressão branca diante de um ebó (oferenda) para Exu, revendo episódios de sua vida, dentre eles traumas, situações de preconceito e discriminação racial, o afastamento de suas origens étnico-culturais em busca de aceitação em uma sociedade racista ${ }^{36}$.

Durante o processo de libertação, Dr. Emanuel, negro e advogado, vai se desvinculando de 
tudo que o prende ao 'mundo dos brancos', inclusive de sua esposa branca (assassinada por ele) e seu anel de doutor, fazendo uma espécie de retorno simbólico à África através da negação do que o autor identifica com os 'valores culturais dos brancos', e da adesão aos 'valores culturais negros de matriz africana', representados, ali, no candomblé. Porém, se podemos falar em uma 'substituição de estereótipos' (considerando que ambas imagens, 'negro assimilado' e 'negro liberto', nesta peça têm um perfil essencializado) é necessário considerarmos a diferença entre a imagem inferiorizada - o tratamento como objeto - que o negro tinha no teatro brasileiro até aquele momento, e o protagonismo que o negro recebeu nas peças produzidas e encenadas pelo TEN. O grupo de Abdias Nascimento se dedicou a incluir o negro enquanto narrador e sujeito de seu próprio enredo, seja nos palcos ou nos estudos sobre o negro, se opondo aos 'lugares comuns' reservados aos afrobrasileiros na dramaturgia e na produção intelectual daquela época que os tinham como coadjuvantes de pouca importância.

No TEN, para além da função de entretenimento, é evidente também a utilização do teatro como meio de intervenção política e pedagógica na questão do preconceito e da discriminação racial. Sua atuação para além dos palcos também o distingue da CNR. O grupo de Abdias Nascimento, investiu na participação de discussões sobre o negro na cultura nacional, e sobre a questão racial, nos meios intelectuais, através de eventos artísticos e políticos, da publicação de livros, e de sua própria imprensa, o jornal Quilombo. Os principais eventos organizados pelo grupo foram: Convenção Nacional do Negro (1945-1946), Conferência Nacional do Negro (1948-1949), I Congresso do Negro Brasileiro (1950), Semana de Estudos Negros (1955), o concurso de artes Cristo Negro (1955), que a imprensa carioca caracterizou como um atentado contra a religião cristã e as $\operatorname{artes}^{37}$. Em maio de 1949, na abertura da Conferência Nacional do Negro, na sede da Associação Brasileira de Imprensa (ABI), cinco anos após a fundação do TEN, Nascimento proferiu um discurso onde defendeu as ações do grupo para além da dramaturgia e atuação cênica:

"O Teatro Experimental do Negro não é, apesar do nome, apenas uma entidade com objetivos artísticos. A necessidade da fundação deste movimento foi inspirada pelo imperativo da organização social da gente de cor, tendo em vista a elevação de seu nível cultural e seus valores individuais. Entretanto, o espírito associativo não é algo inato. Ou, melhor ainda, o espírito associativo é atributo da massa esclarecida e de elevado padrão cultural. Daí ser quase impossível, como se pode depreender da

37 Elisa Larkin Nascimento, Sortilégio da Cor. P.242 
observação da vida brasileira, associar homens e mulheres em função, apenas, de objetivos sociais" ${ }^{38}$.

$\mathrm{O}$ documento do qual destacamos o trecho acima relata os objetivos do TEN nos primeiros anos de sua trajetória. Neste trecho, assim como em outras passagens do texto, fica evidente a postura de vanguarda reivindicada pelo grupo, ao afirmar que "o espírito associativo é atributo da massa esclarecida e de elevado padrão cultural". Neste aspecto o TEN não se diferenciou de outras organizações políticas que o antecederam como a Frente Negra Brasileira (FNB), ou que com ele coexistiram como a União dos Homens de Cor (UHC), o Partido Comunista do Brasil (PCB) e a União Nacional dos Estudantes (UNE), que também assumiram posturas vanguardistas, vendo nas "massas" um potencial agente de transformação social que deveria ser "despertado", ou induzido, através da elevação cultural e da conscientização política, que seria o papel das "elites intelectuais". Neste ponto, o TEN mantém uma relação de continuidade com seus antecessores no movimento negro: a FNB e a imprensa negra da primeira metade do século XX, que reivindicavam o papel de "intelligentsia negra" para falar sobre os negros, e tinha como estratégia de integração social a "elevação do nível cultural” dos afro-brasileiros.

Um dos aspectos que diferenciava o grupo de Abdias do Nascimento de seus antecessores no movimento social afro-brasileiro é o esforço em participar dos debates sobre o negro junto com a intelectualidade branca, como nos mostra a cooperação de artistas e intelectuais brancos na dramaturgia, no jornal Quilombo, e em eventos produzidos pelo TEN. Outro aspecto que o diferencia das primeiras organizações negras brasileiras, é sua conexão com o movimento negro internacional, sobretudo a negritude francófona e o movimento negro estadunidense, como nos mostram as referências à revista Présence Africaine editada por Alioune Diop, e traduções de artigos do jornal The Crisis editada por W.E.B. Du Bois ${ }^{39}$.

A necessidade de organização da população negra - ou "gente de cor", nas palavras de Nascimento, termo bastante usado para se referir aos negros naquela época - era, portanto, tarefa de uma intelectualidade negra. O teatro era uma estratégia, não apenas de colocar as questões sobre o negro em debate, mas, também, de atrair as "massas" para o debate. A linguagem artística

38 Abdias do Nascimento, "Espírito e fisionomia do Teatro Experimental do Negro". In: Quilombo, n³, junho de 1949. P.11

39 Barbosa, "O TEN e a Negritude Francófona no Brasil: recepção e inovações"; Macedo, Abdias do Nascimento: trajetória de um negro revoltado; Nascimento, Quilombo: vida, problemas e aspirações do negro. 
(dramatúrgica) era um convite à reflexão sobre as condições do negro na sociedade brasileira e uma forma de driblar as dificuldades de, no Brasil, "associar homens e mulheres em função, apenas, de objetivos sociais" (nas palavras de Nascimento). Tais dificuldades de organizar-se politicamente para debater questões sociais, muito devem ao período anterior, recém-terminado, de ditadura do Estado Novo (1937-1945), que perseguiu as organizações políticas e civis, fechando-as, ou passando a controlá-las.

Organizar-se em torno de um teatro negro era menos arriscado, e poderia ser mais socialmente aceitável na época do que fundar um partido político negro. No entanto, ao longo da trajetória do TEN ficam cada vez mais evidentes os objetivos políticos de integração social do negro e de combate à discriminação racial, através da ação cultural. Embora o TEN não tenha tido vinculação direta com partidos políticos, teve o apoio declarado de autoridades dos mais variados matizes políticos como o senador Hamilton Nogueira (UDN), amigo pessoal de Abdias Nascimento; veiculou através do jornal Quilombo (n6 e 7/8, ano de 1950) campanha eleitoral de candidatos negros dentre eles o jornalista Geraldo de Campos Oliveira para deputado federal em São Paulo, e o próprio Abdias Nascimento para vereador do Distrito Federal, pelo Partido Social Democrático (PSD). Em 1947 Abdias já havia se candidatado a vereador do Distrito Federal pelo Partido Trabalhista Brasileiro (PTB), que apoiava Getúlio Vargas. Este mesmo partido em novembro de 1946 fundou o Diretório Negro do qual participavam alguns membros do TEN como o próprio Abdias, Sebastião Rodrigues Alves, Aguinaldo Camargo, o poeta argentino Efrain Tomás Bó, e membros do Partido Comunista Brasileiro (PCB), dentre eles Solano Trindade ${ }^{40}$.

Embora não apareça uma definição detalhada do conceito de "teatro experimental" no discurso de Nascimento, sabemos que trata-se de uma investida nova no cenário dramatúrgico da época, tanto na estética quanto nas temáticas abordadas. Por tratar-se também de um teatro que reivindicava para si uma missão, para além dos palcos, de intervir nas questões sociais de maneira pedagógica e também sociológica, podemos propor a hipótese de que o conceito de "experimental" associe-se a essa postura polivalente, que combinava a linguagem artística com pesquisas, debates sociológicos e ação pedagógica. A parceria com intelectuais como Edison Carneiro, Arthur Ramos, Gilberto Freyre, Florestan Fernandes, Roger Bastide, que publicaram no periódico do TEN e participaram de seus eventos, a participação do sociólogo Guerreiro Ramos, que além das

40 O PTB fundou em 21 de novembro de 1946 o Diretório Negro, com a finalidade de atuar em questões pertinentes a população afro-brasileira. Ver: Elisa Larkin Nascimento, Abdias Nascimento: grandes vultos que honram o senado. P. 175 
pesquisas, publicações, foi responsável pela introdução do psicodrama na formação dos atores, evidenciam esta busca por um viés também sociológico do TEN. Essa busca por um viés sociológico se relaciona ao objetivo de compreender a sociedade de sua época para nela atuar. $\mathrm{O}$ TEN formou-se em um período em que era atribuído à classe intelectualizada o papel de refletir e intervir nos assuntos relevantes para a nação. Abdias Nascimento e Guerreiro Ramos reivindicavam que os negros participassem também como sujeitos, e não apenas como tema, nestes assuntos.

Sobre a concepção de um teatro experimental feito por negros, fazendo referência ao grupo de Abdias Nascimento, Florestan Fernandes comentou:

\begin{abstract}
"A ideia de um teatro experimental nasce de uma formulação moderna e positiva: a questão está em saber como manejá-la. A rigor, o teatro que possuíamos (excetuando-se certas manifestações de teor folclórico ou popularesco e a presença deformada ou autêntica do negro no antigo teatro erudito brasileiro), como as demais manifestações intelectuais, era de brancos e para brancos. Engendrar um teatro negro significa dar oportunidade de formação e de afirmação artísticas ao negro - algo em si mesmo revolucionário, que implicava revisões de estereótipos negativos para o negro e na eliminação progressiva de barreiras que proscreviam o negro de nossa vida intelectual produtiva e criadora. Mas um teatro experimental tem de visar a outros fins. Ou seja, ao dar canais de expressão à capacidade criadora do negro e ao redefinir representações sobre suas aptidões intelectuais ou morais, ele precisa concorrer para modificar alguma coisa em determinada direção. Isso levanta várias questões, ligadas à elaboração dos dramas, à composição dos auditórios e às influências educativas do teatro" ${ }^{41}$.
\end{abstract}

\title{
Conclusões
}

As maneiras como os afro-brasileiros foram representados nas artes cênicas dos diferentes períodos, nos informam sobre as ideologias dominantes de cada época. Os papéis reservados aos negros nos palcos, a partir de meados do século XIX, têm muito a ver com os setores sociais para os quais os ex-escravizados e seus descendentes foram sendo empurrados na medida em que conseguiam ser alforriados durante o regime escravocrata, e no pós-abolição. A sociedade brasileira convive com o legado racista que a estratifica, mantendo os brancos em condições privilegiadas, e os negros e indígenas majoritariamente nos setores mais explorados e privados de direitos sociais.

Junto com as desigualdades materiais, os estereótipos e imagens pejorativas sobre os afrobrasileiros persistiram na literatura, no teatro, no cinema, posteriormente nas telenovelas, na

41 Florestan Fernades, O negro no mundo dos brancos. P.222 
publicidade. Entendemos que há uma relação intrínseca entre a objetividade da espoliação material da população negra e a subjetividade das representações negativas no campo simbólico. No entanto, não consideramos que subjetividade (simbólico) seja um mero reflexo da objetividade (condições materiais); trata-se de uma relação dialética, ou seja, um movimento de reciprocidade - e complementaridade - entre ambos os campos onde um não é menos importante que o outro ${ }^{42}$.

Sendo assim, não entendemos a arte como um mero reflexo da sociedade, mas a compreendemos na mesma relação dialética que no início deste artigo atribuímos ao racismo: um produto social que também produz o social. Portanto, as representações dos negros em papéis subalternos nos palcos, nos diferentes períodos históricos, expressavam um universo que convinha ser preservado a qualquer nas estruturas sociais do capitalismo periférico que aqui se implementou: os brancos no poder, e os negro subservientes.

Frente a esse problema intelectuais, artistas e militantes negros seguem denunciando e combatendo o racismo, como vem sendo feito historicamente ao longo da trajetória do movimento negro do pós-abolição desde as organizações que ficaram conhecidas como Imprensa Negra aos dias de hoje, em torno de distintas investidas e formas de organização.

\section{Bibliografia}

BACELAR, Jeferson, “A história da Companhia Negra de Revistas" In: Revista de Antropologia. São Paulo, USP, 2007, v. 50, n¹.

BARBOSA, Muryatan Santana. "O TEN e a Negritude Francófona no Brasil: recepção e inovações”. In: Revista Brasileira de Ciências Sociais. Vol. 28, º 81, fevereiro, 2013.

FANON, Frantz. Os condenados da Terra. Ed. UFJF, Minas Gerais, 2010.

FANON, Frantz. Pele negra, máscaras brancas. Bahia, Edufba, 2008.

FERNANDES, Florestan. A integração do negro na sociedade de classes. São Paulo, Ática, 1978 [1965].

FERNANDES, Florestan. O Negro no Mundo dos Brancos. São Paulo, Global editora, 2007.

GUIMARÃES, Antonio Sergio Alfredo. Classes, raças e democracia. São Paulo, Ed. 34, 2002.

GUINSBURG, Jacó; FARIA, João Roberto Gomes; LIMA, Mariangela Alves de. Dicionário do

42 Para uma analise em torno do racismo nos campos material e simbólico: Frantz Fanon, Pele negra, máscaras brancas, e Os condenados da Terra. 
Teatro Brasileiro: temas, formas e conceitos. São Paulo: Perspectiva; SESC, 2009.

HASENBLAG, Carlos Alfredo; SILVA, Nelson do Valle. Estrutura social, mobilidade e raça. Rio de Janeiro: Vértice Editora, 1988.

NASCIMENTO, Abdias do. Dramas para Negros e Prólogo para Brancos. Rio de Janeiro: TEN, 1961.

NASCIMENTO, Abdias. "Espírito e fisionomia do Teatro Experimental do Negro". In: Quilombo: vida, problemas e aspirações do negro, $\mathrm{n}^{\circ} 3$, junho de 1949.

NASCIMENTO, Abdias do. O Genocídio do Negro Brasileiro. Rio de Janeiro: Paz e Terra, 1978.

NASCIMENTO, Elisa Larkin. Sortilégio da cor - identidade raça e gênero no Brasil. São Paulo: Selo Negro, 2003.

NASCIMENTO, Elisa Larkin. Abdias Nascimento: grandes vultos que honram o senado. Brasília: Senado Federal, Coordenação de Edições Técnicas, 2014.

NEPOMUCENO, Nirlene. Testemunhos de poéticas negras: de Chocolat e a Companhia Negra de Revista no Rio de Janeiro (1926-1927). Dissertação de mestrado em história, PUC, São Paulo, 2006.

MACEDO, Márcio José de. Abdias do Nascimento: trajetória de um negro revoltado (1914-1968). Dissertação de mestrado em sociologia, USP, São Paulo, 2005.

MARX, Karl. A ideologia alemã. São Paulo: Boitempo Editorial, 2007.

MENDES, Miriam Garcia. O negro e o teatro brasileiro. São Paulo: Hucitec; Rio de Janeiro: Instituto Brasileiro de Arte e Cultura; Brasília: Fundação Cultural Palmares, 1993.

MOURA, Christian Fernando dos Santos. O Teatro Experimental do Negro - Estudo da personagem negra em duas Peças encenadas (1947-1951). Dissertação de mestrado em Artes Cênicas, Unesp, São Paulo, 2008.

MOURA, Clóvis. Dialética radical do Brasil negro. São Paulo: Fundação Maurício Grabois; Anita Garibaldi, 2014.

MUNANGA, Kabengele. Rediscutindo a mestiçagem: identidade nacional versus identidade negra. 3. ed. Belo Horizonte: Autêntica, 2008.

ROCHA, Gabriel dos Santos. O negro como tema e sujeito na produção intelectual de Abdias do Nascimento, 1944-1968. Dissertação de Mestrado, História Social, FFLCH/USP, 2016. 